\title{
Spatial distribution of shore crabs Carcinus maenas in an intertidal environment in relation to their morphology, prey availability and competition
}

\author{
Isabel M. Smallegange ${ }^{1,3, *}$, C. (Toos) G. E. van Noordwijk ${ }^{1,4}$, Jaap van der Meer ${ }^{1,2}$, \\ Henk W. van der Veer ${ }^{1}$ \\ ${ }^{1}$ Department of Marine Ecology, Royal Netherlands Institute for Sea Research (NIOZ), PO Box 59, 1790 AB, Den Burg, \\ Texel, The Netherlands \\ ${ }^{2}$ Institute of Ecological Science, Free University, De Boelelaan 1085, 1081 HV Amsterdam, The Netherlands \\ ${ }^{3}$ Present address: Division of Biology, Imperial College London, Silwood Park, Ascot, Berkshire SL5 7PY, UK \\ ${ }^{4}$ Present address: Department of Animal Ecology, Stichting Bargerveen / Radboud University Nijmegen, Toernooiveld 1, \\ 6525 ED Nijmegen, The Netherlands
}

\begin{abstract}
Identifying the key determinants of benthic predator distributions is crucial in understanding the dynamics of predator and prey populations in intertidal environments. In this paper, we assessed the roles of predator morphology, prey availability and competition in determining the distribution of an important benthic predator, the shore crab Carcinus maenas (L.). The abundance of shore crabs at high tide on 3 intertidal mudflats in the Dutch Wadden Sea was assessed in relation to distance to the nearest gully, size, sex and colour of the crabs. Furthermore, food availability (bivalves, crustaceans, polychaetes) in the sampling sites was measured. Half of all crabs were found in the gullies adjacent to each mudflat, where the abundance of a prey species (the large brown shrimp Crangon crangon) was also highest. The spatial distribution of crabs between the gullies and the mudflats depended in an interactive way on the colour morph and sex of individuals. Comparing observed distributions of crabs with those predicted from a recently developed ideal free distribution model showed that crabs did not distribute themselves optimally in terms of maximising food uptake and minimising the strength of competition from conspecifics. The results highlight the yet underrated role of shore crabs as a potentially important predator of shrimps, and the need to incorporate morphological characteristics and different prey types into ideal free distribution models to test the optimal foraging behaviour of benthic crabs.
\end{abstract}

KEY WORDS: Blue mussel $\cdot$ Mytilus edulis $\cdot$ Cockle $\cdot$ Cerastoderma edule $\cdot$ Intertidal $\cdot$ Generalized functional response $\cdot 2$-phenotypes interference model

Resale or republication not permitted without written consent of the publisher

\section{INTRODUCTION}

The patchy distribution of individuals in marine benthic environments can be related to variation in environmental conditions (Vernberg \& Vernberg 1983), morphological characteristics of predators (Styrishave et al. 2004), and biological interactions such as competition (Whittaker \& Levin 1977). For example, predators may lose prey items to competitors or waste time in aggressive interactions, resulting in decreased feeding rates. This poses a challenge for foraging predators to maximise food uptake while minimising the negative effects of competition. Identifying the key determinants of benthic predator distributions is crucial in understanding the dynamics of predator and prey populations in marine environments. In this paper, we assessed the role of predator morphology, prey availability and competition in determining the distribution 
of an important benthic predator, the shore crab Carcinus maenas (L.).

The shore crab occurs abundantly along European Atlantic coasts and estuaries, and has invaded the North American Atlantic coasts (Berrill \& Arsenault 1982) and some areas in southern Africa, Australia and the Pacific coast of North America (Cohen et al. 1995). The local occurrence of shore crabs varies with habitat characteristics such as tidal regime and water depth, and depends on their size, sex and colour. Generally, males are more migratory than females, and green crabs, which are in early or normal intermoult, are more migratory than red crabs, which are in prolonged intermoult (Crothers 1968, McGaw \& Naylor 1992, Warman et al. 1993, Aagaard et al. 1995). Red crabs are competitively stronger than similarly sized green crabs (Kaiser et al. 1990), but this is achieved at the expense of lower physiological tolerance, as green crabs are more resilient to environmental extremes (McGaw \& Naylor 1992, Reid et al. 1997, Styrishave et al. 2004) and can therefore exploit more foraging areas than red crabs.

We studied the spatial distribution of shore crabs on 3 intertidal mudflats in the western Wadden Sea (The Netherlands) where we sampled shore crabs and their prey: bivalves, polychaetes and crustaceans (Afman 1980, Pihl 1985, Ansell et al. 1999). Since morphology influences the distribution of shore crabs, we scored their sex, size and colour. Because shore crabs undertake long feeding migrations from the gullies to foraging areas on the adjacent mudflat (Hunter \& Naylor 1993), we incorporated the gully-mudflat distance into the sampling design. With this field study, we aimed to assess the relative importance of crab morphology and prey availability in different feeding areas in determining shore crab distributions. Furthermore, we applied ideal free distribution (IFD) theory to the field data to test if crabs distributed themselves optimally in terms of balancing competition from conspecifics and feeding opportunities in different feeding areas. IFD theory assumes that animals have perfect knowledge of feeding areas (ideal), and that they are free to move to the area that maximises food rewards (Fretwell \& Lucas 1969). Animals will then distribute themselves such that no individual can improve its feeding rate by moving to another area. IFD theory has been successfully used in the field to understand the way animals distribute themselves (Bautista et al. 1995, Milinski et al. 1995, Alonso et al.
1997). To formulate ideal free predictions of the distribution of crabs, we used the 2-phenotypes interference model (Smallegange \& van der Meer 2009). This model gives the expected per capita feeding rate for dominant and subordinate competitors as a function of prey density and competitor type and density, and is based on laboratory observations of foraging shore crabs (Smallegange et al. 2006, Smallegange \& van der Meer 2007). The 2-phenotypes interference model assumes that predators forage on a single prey type. In our IFD tests, we focused on 2 prey categories. Up to $50 \%$ of the diet of shore crabs in the Wadden Sea consists of brown shrimps Crangon crangon (Afman 1980); hence, this was our first prey category. The second prey category was infauna, which consisted mainly of bivalve prey species. The IFD tests (1) compared the observed with the predicted distributions of shore crabs, and (2) tested whether the expected feeding rates of crabs (calculated using the field data) were in line with ideal free predictions.

\section{MATERIALS AND METHODS}

Sampling sites. The 3 intertidal mudflats in the study area (Balgzand, Ballastplaat and Waardgronden) are located in the western Dutch Wadden Sea (Fig. 1). Each tidal flat was adjacent to a major gully and was 0 to $1.2 \mathrm{~m}$ above mean low-water spring tide. On each tidal flat, 3 transects were established perpendicular to

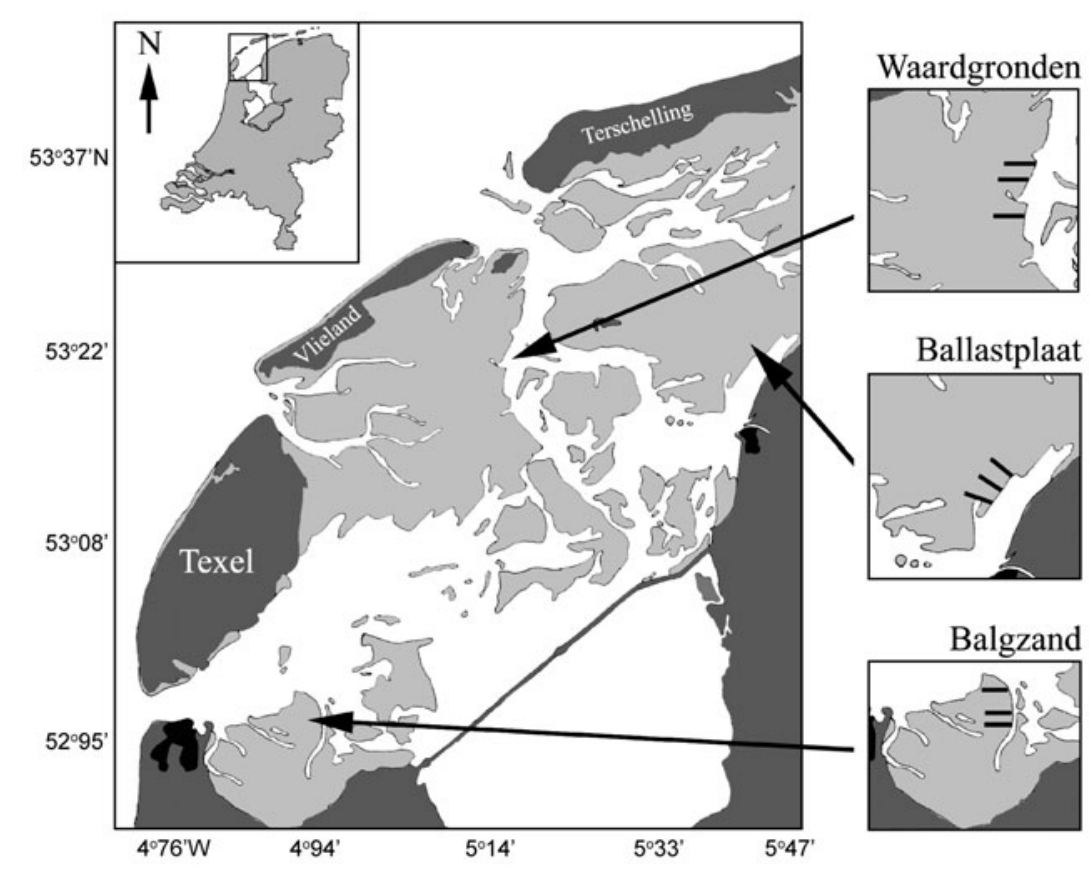

Fig. 1. Locations of the 3 transects on each tidal flat (Balgzand, Ballastplaat and Waardgronden, in grey) in the Western Wadden Sea, The Netherlands 
the gully (Fig. 1). The position of each transect was randomly selected. Perpendicular to each transect, samples were taken in the gully and on each tidal flat at 5 distances from the gully: 0 (on the rim of the gully), $100,600,1100$ and $1600 \mathrm{~m}$ away from the gully. We chose these specific locations to cover the foraging range of shore crabs: at low tide, adult shore crabs (>35 mm carapace width, CW) retreat to deeper waters such as gullies, whereas juvenile shore crabs $(<35 \mathrm{~mm}$ CW) burrow on the tidal flats (Hunter \& Naylor 1993). At high tide, adult shore crabs move from the gullies onto the tidal flats to forage and can make return journeys of $400 \mathrm{~m}$ to $1 \mathrm{~km}$ (Crothers 1968, Dare \& Edwards 1981, M. Bergman \& T. H. W. van der Veer unpubl. data). Samples were taken starting at $1.5 \mathrm{~h}$ before to $1.5 \mathrm{~h}$ after high-water spring tide. Since sampling was conducted during spring tide, the tidal flats had been completely exposed during low tide, ensuring that all adult crabs on the tidal flats had migrated there in the last 6 h (Hunter \& Naylor 1993). Samples were collected on June 8 (Balgzand), July 5 and 6 (Ballastplaat), and July 8 and 21 (Waardgronden), 2004. Shore crabs prefer to forage at night (Afman 1980, Ansell et al. 1999), but sampling was done during daytime for logistical reasons. We assume, however, that a sufficient number of crabs still forages during the day, allowing us to draw conclusions on their spatial distribution in relation to prey availability.

Sampling methods. Shore crabs feed on bivalves (such as the mussels Mytilus edulis, cockles Cerastoderma edule and sand gapers Mya arenaria; Reise 1985, Sanchez-Salazar et al. 1987, van der Veer et al. 1998), polychaetes (Ansell et al. 1999), and crustaceans (mainly brown shrimps; Afman 1980, Pihl 1985). At each sampling site, we sampled both shore crabs and their prey (shrimps, other crustaceans, bivalves, and polychaetes). Samples of shore crabs and shrimps were collected in the gullies by towing a $2 \mathrm{~m}$ beam trawl (mesh size $5.5 \mathrm{~mm}$ ) over a distance of $\sim 50 \mathrm{~m}$, and on the tidal flats by towing a $1 \mathrm{~m}$ beam trawl over a distance of $\sim 100 \mathrm{~m}$ (mesh size $5.5 \mathrm{~mm}$ ). The exact length of each haul was recorded using a measuring wheel that was attached to the beam trawl. A day after collection, shore crabs were sexed and the colour of their abdomen was determined using a colour index ranging from green (1) to shades of yellow and orange (2-9) to red (10) (Lee et al. 2005). Shore crabs were sized to the nearest $5 \mathrm{~mm}$ according to their CW. For the analyses, crabs were categorized in 2 colour and 2 size classes: either green (colour codes 1-5) or red (colour codes 6-10) and as juve- niles (CW between 10 and $35 \mathrm{~mm}$ ) or adults (carapace width $>35 \mathrm{~mm}$ ). Crabs $<10 \mathrm{~mm}$ were excluded from the analyses because the catch efficiency for crabs of this size was too low to provide accurate abundance estimates (H. W. van der Veer unpubl. data). Shrimps were frozen after collection and later sized to the nearest $5 \mathrm{~mm}$ and assigned to 1 of 2 size classes: $0-25 \mathrm{~mm}$ carapace length and 25-65 mm carapace length. Shore crab and brown shrimp abundances were expressed in no. per $100 \mathrm{~m}^{2}$.

Immediately after epibenthic sampling, 3 box corer (15.6 cm diameter, $20 \mathrm{~cm}$ depth) samples were taken twice (to reduce variability) at each sampling location in the gully, and 5 corer $(16.6 \mathrm{~cm}$ diameter, $20 \mathrm{~cm}$ depth) samples were taken twice at each sampling location on the tidal flats for analyses of the infauna. Samples were sieved (mesh size $1.1 \mathrm{~mm}$ ), placed in plastic bags and maintained in a refrigerator for $<24 \mathrm{~h}$. The day after collection, the infauna in the samples was sorted to species level or coarse taxonomic groups, and only the infauna that was potential prey for shore crabs (Table 1) was processed. The selected infauna was dried for $3 \mathrm{~d}$ in an oven at $60^{\circ} \mathrm{C}$ and incinerated at $550^{\circ} \mathrm{C}$ for $2 \mathrm{~h}$ to determine ash-free dry mass (AFDM). Shells of bivalves were removed prior to determining the AFDM.

Data analysis. Using redundancy analysis (RDA), we related the composition of the shore crab population to variation in the environment. Shore crab abundances (no. per $100 \mathrm{~m}^{2}$ ) were split into 8 classes based on life stage (juvenile, adult), sex (male, female) and colour (green, red). The environmental variables used were distance from the gully $(0,3,100,600,1100$ and $1600 \mathrm{~m}$ ) and prey availability (abundance of infauna, g AFDM m ${ }^{-2}$; and abundance of brown shrimps, no. per $100 \mathrm{~m}^{2}$ ). Due to the presence of 0 observations, the abundances of shore crabs, brown shrimps and infauna were $\log (1+$ value $)$-transformed.

Table 1. Species and size criteria used to determine potential prey for shore crabs Carcinus maenas in the benthos samples. Shell lengths were based on maximum shell lengths and measured to the nearest mm using electronic calipers

\begin{tabular}{|lcl|}
\hline Species & Criteria & Source \\
\hline Annelids & $\begin{array}{c}\text { All except } \\
\text { Arenicola marina }\end{array}$ & R. Dekker (pers. comm.) \\
Macoma balthica & $>5 \mathrm{~mm}$ & R. Dekker (pers. comm.) \\
Tellina spp. & $>5 \mathrm{~mm}$ & R. Dekker (pers. comm.) \\
Cerastoderma edule & $5-20 \mathrm{~mm}$ & Mascaró \& Seed (2000, 2001) \\
Mytilus edulis & $5-25 \mathrm{~mm}$ & Mascaró \& Seed (2000, 2001) \\
Ensis americanus & $>5 \mathrm{~mm}$ & I. M. Smallegange (unpubl. data) \\
Mya arenaria & $>5 \mathrm{~mm}$ & Mitchell et al. (2003) \\
Crustacea & All except & Afman (1980) \\
& Carcinus maenas & \\
\hline
\end{tabular}


An assumption of RDA is that crab abundances increase monotonically with increasing values of the environmental variables. We assumed this to be the case, especially with respect to the prey variables. The analysis and graphical displays were performed in Canoco 4 (ter Braak \& Šmilauer 1998).

Using univariate split-plot analyses, we investigated how the abundance of shore crabs, shrimps, and infaunal density varied between and within tidal flats. The basic statistical model of each analysis included transects as plots, tidal flat (TF, $2 \mathrm{df}$ ) as an among-plots factor and distance from the gully (D, $5 \mathrm{df}$ ) as a withinplots factor. To analyse shore crab abundance (no. per $100 \mathrm{~m}^{2}$ ), we added the within-plots factors sex (Se, $1 \mathrm{df}$ ), colour (C, $1 \mathrm{df}$ ) and body size ( $\mathrm{Si}, 1 \mathrm{df})$ to the basic model. To analyse shrimp abundance (no. per $100 \mathrm{~m}^{2}$ ), the within-plots factor body size ( $\mathrm{Si}, 1 \mathrm{df}$ ) was added to the basic model. Abundances were log-transformed to conform with the normality assumption of ANOVAs, and analyses were performed in Systat 10 (SPSS). Logtransformed shore crab abundances violated the normality assumption; therefore, a permutation approach was used to obtain significance levels (Manly 1997). A total of 1000 random permutations of all observations were generated and each time, the analysis was performed as a complete data analysis (in MatLab 6.5). The $F$-value obtained using the observed data was compared with the $95 \%$ point of the distribution of $F$-values obtained from the random permutations, which we refer to as the critical $F$-value.

\section{RESULTS}

\section{Shore crab abundance and environmental variation}

The first and second RDA axis, respectively, explained 20 and $1 \%$ of the total variance in the shore crab abundance data. The first RDA axis was mainly due to a gradient in large shrimp abundance (correlations between first axis and infauna, small shrimps, large shrimps and distance were $-0.24,-0.55,0.81$ and -0.52 , respectively), while the second axis was mainly due to a gradient in small shrimp abundance (correlations between second axis and infauna, small shrimps, large shrimps and distance were $-0.21,-0.72,-0.52$ and -0.61 , respectively). No precise inferences could be made for red juvenile males and green adult females as their location in the ordination diagram was too close to the origin (Fig. 2). The abundance of adult crabs and green juveniles of both sexes correlated positively with the abundance of large shrimps (inferred from the narrow angles between the large shrimps arrow and the adult crab and green juvenile lines; Fig. 2). The abundance of adults and red juvenile

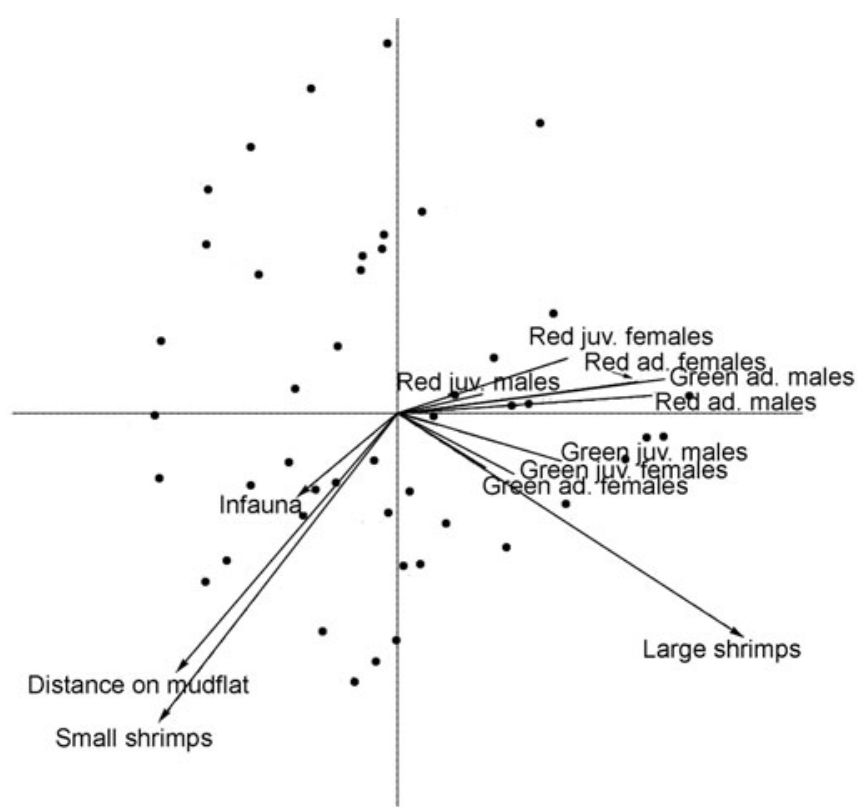

Fig. 2. Carcinus maenas. Redundancy analysis (RDA) ordination diagram with the different crab classes (lines) (ad.: adult, juv.: juvenile), sites (dots) and environmental variables (arrows). The horizontal and vertical axes are the first and second RDA axes, respectively. Arrows pointing in roughly the same direction indicate a high positive correlation; those crossing at right angles indicate near- 0 correlation, and those pointing in roughly opposite directions indicate a high negative correlation (the cosine of the angle between a crab class and an environmental arrow approximates their correlation coefficient). Inferences about the correlations of crab classes near the centre of the diagram are imprecise

females correlated negatively with that of small shrimps and distance on the mudflat (inferred from the wide angles between the small shrimps and distance on mudflat arrows and the adult crab and red juvenile female lines; Fig. 2). The abundance of red juvenile females showed a weak positive correlation with the abundance of large shrimps.

\section{Variations in shore crab abundance between and within tidal flats}

The statistical model contained 5 factors and therefore many interactions. Several main effects, 2- and 3 -way interactions were significant (Table 2). Results were interpreted from the highest order interaction down to the main effects.

Overall, shore crab abundance was highest in the gully adjacent to each tidal flat. However, crab abundances on the tidal flats differed between the sexes and between tidal flats (significant interaction $\mathrm{D} \times \mathrm{Se} \times$ TF; Table 2, Fig. 3). On Balgzand, more females than males were present in the gully. Their abundances on the tidal flat did not differ and were generally lower in 
Table 2. Carcinus maenas. ANOVA of (log-transformed) abundance. $F$-values in bold are higher than the critical $F$-value $\left(F_{\text {crit. }}\right)$ at $\alpha=0.05$

\begin{tabular}{|c|c|c|c|c|}
\hline Factor & $\mathrm{df}$ & MS & $F$ & $F_{\text {crit. }}$ \\
\hline \multicolumn{5}{|l|}{ Between plots } \\
\hline Tidal flat (TF) & 2 & 3.6 & 5.5 & 5.2 \\
\hline Error & 6 & 0.7 & & \\
\hline \multicolumn{5}{|l|}{ Within plots } \\
\hline Distance (D) & 5 & 31.2 & 9.7 & 2.5 \\
\hline $\mathrm{D} \times \mathrm{TF}$ & 10 & 4.0 & 1.3 & 2.1 \\
\hline Error & 30 & 3.2 & & \\
\hline Sex (Se) & 1 & 6.3 & 44.1 & 5.5 \\
\hline $\mathrm{Se} \times \mathrm{TF}$ & 2 & 3.7 & 26.1 & 4.4 \\
\hline Error & 6 & 0.1 & & \\
\hline Colour (C) & 1 & 249.1 & 318.5 & 5.8 \\
\hline $\mathrm{C} \times \mathrm{TF}$ & 2 & 0.3 & 0.4 & 4.4 \\
\hline Error & 6 & 0.8 & & \\
\hline Size (Si) & 1 & 73.8 & 70.1 & 5.8 \\
\hline $\mathrm{Si} \times \mathrm{TF}$ & 2 & 17.0 & 16.1 & 5.1 \\
\hline Error & 6 & 1.1 & & \\
\hline $\mathrm{D} \times \mathrm{Se}$ & 5 & 0.7 & 3.0 & 2.4 \\
\hline $\mathrm{D} \times \mathrm{Se} \times \mathrm{TF}$ & 10 & 0.9 & 3.9 & 2.2 \\
\hline Error & 30 & 0.2 & & \\
\hline $\mathrm{D} \times \mathrm{C}$ & 5 & 1.0 & 1.5 & 2.6 \\
\hline $\mathrm{D} \times \mathrm{C} \times \mathrm{TF}$ & 10 & 0.6 & 0.9 & 2.2 \\
\hline Error & 30 & 0.7 & & \\
\hline $\mathrm{D} \times \mathrm{Si}$ & 5 & 1.3 & 3.1 & 2.6 \\
\hline $\mathrm{D} \times \mathrm{Si} \times \mathrm{TF}$ & 10 & 1.3 & 3.1 & 2.2 \\
\hline Error & 30 & 0.4 & & \\
\hline $\mathrm{Se} \times \mathrm{C}$ & & 16.8 & 156.1 & 6.1 \\
\hline $\mathrm{Se} \times \mathrm{C} \times \mathrm{TF}$ & 2 & 1.9 & 17.3 & 5.3 \\
\hline Error & 6 & 0.1 & & \\
\hline $\mathrm{Se} \times \mathrm{Si}$ & 1 & 3.9 & 5.7 & 6.2 \\
\hline $\mathrm{Se} \times \mathrm{Si} \times \mathrm{TF}$ & 2 & 0.1 & 0.1 & 5.2 \\
\hline Error & 6 & 0.6 & & \\
\hline $\mathrm{C} \times \mathrm{Si}$ & 1 & 83.9 & 216.4 & 5.4 \\
\hline $\mathrm{D} \times \mathrm{Se} \times \mathrm{TF}$ & 2 & 3.8 & 9.7 & 5.3 \\
\hline Error & 6 & 0.4 & & \\
\hline $\mathrm{D} \times \mathrm{Se} \times \mathrm{C}$ & 5 & 1.9 & 4.5 & 2.5 \\
\hline $\mathrm{D} \times \mathrm{Se} \times \mathrm{C} \times \mathrm{TF}$ & 10 & 0.6 & 1.5 & 2.2 \\
\hline Error & 30 & 0.4 & & \\
\hline $\mathrm{D} \times \mathrm{Se} \times \mathrm{Si}$ & 5 & 1.2 & 2.5 & 2.5 \\
\hline $\mathrm{D} \times \mathrm{Se} \times \mathrm{Si} \times \mathrm{TF}$ & 10 & 0.2 & 0.4 & 2.2 \\
\hline Error & 30 & 0.5 & & \\
\hline $\mathrm{D} \times \mathrm{C} \times \mathrm{Si}$ & 5 & 0.3 & 1.1 & 2.4 \\
\hline $\mathrm{D} \times \mathrm{C} \times \mathrm{Si} \times \mathrm{TF}$ & 10 & 0.5 & 1.8 & 2.1 \\
\hline Error & 30 & 0.3 & & \\
\hline $\mathrm{Se} \times \mathrm{C} \times \mathrm{Si}$ & 1 & 1.4 & 9.3 & 7.1 \\
\hline $\mathrm{Se} \times \mathrm{C} \times \mathrm{Si} \times \mathrm{TF}$ & 2 & 0.4 & 2.6 & 4.8 \\
\hline Error & 6 & 0.2 & & \\
\hline $\mathrm{D} \times \mathrm{Se} \times \mathrm{C} \times \mathrm{Si}$ & 5 & 0.3 & 0.6 & 2.5 \\
\hline $\mathrm{D} \times \mathrm{Se} \times \mathrm{C} \times \mathrm{Si} \times \mathrm{TF}$ & 10 & 0.3 & 0.5 & 2.2 \\
\hline Error & 30 & 0.5 & & \\
\hline
\end{tabular}

the gully except for a peak at $600 \mathrm{~m}$ from the gully. In contrast to the gully on Balgzand, more males than females were present in the gully on Ballastplaat, but both decreased in abundance with increasing distance from the gully. On Waardgronden, the difference in the distribution patterns of males and females was less pronounced: their abundance was highest in the gully and decreased with increasing distance from the gully, although the abundance of females increased again at $1600 \mathrm{~m}$ from the gully. Despite these subtle differences in how males and females were distributed on the tidal flats, the general pattern was that on Ballastplaat, and to a lesser extent on Waardgronden, the abundance of males was higher than that of females, whereas the abundance of females was higher than that of males on Balgzand (highly significant interaction $\mathrm{Se} \times \mathrm{TF}$ ).

On Balgzand, the abundance of males and females showed a peak at $600 \mathrm{~m}$ from the gully (Fig. 3). This peak was mainly due to the high abundance of juvenile crabs at this location, whereas the abundance of adults showed little variation with increasing distance from the gully. On Ballastplaat and on Waardgronden, juveniles and adults were distributed in a different manner (significant interaction $\mathrm{D} \times \mathrm{Se} \times \mathrm{TF}$; Table 2, Fig. 3). On Ballastplaat, the abundance of juveniles decreased and then increased again with increasing distance from the gully, whereas the abundance of adults decreased with increasing distance from the gully. On Waardgronden, the abundance of both juveniles and adults decreased with increasing distance from the gully. Despite these differences in the distribution patterns between juveniles and adults on the tidal flats, the fact that the interaction $\mathrm{Si} \times \mathrm{TF}$ was highly significant indicates that the difference in abundance between juveniles and adults was nevertheless much higher on Balgzand than on Ballastplaat or Waardgronden. Since the interactions $\mathrm{Se} \times \mathrm{Si}$ and $\mathrm{Se} \times \mathrm{Si} \times \mathrm{TF}$ were not significant, the aforementioned patterns were probably the same for both males and females.

For the 2 colour groups, i.e. crabs that were green(ish) and those that were red(dish), abundance differed with distance from the gully and these distribution patterns in turn differed between males and females (significant interaction $\mathrm{D} \times \mathrm{Se} \times \mathrm{C}_{i}$ Table 2, Fig. 3). Both the abundances of green and red males decreased with increasing distance from the gully. The abundance of red females also decreased with increasing distance from the gully, yet the abundance of green females first decreased and then increased with increasing distance from the gully. Furthermore, the difference in the abundances of green and red crabs was greater for males than for females (highly significant interaction $\mathrm{Se} \times \mathrm{C}$ ). The latter interaction also differed between tidal flats (significant interaction Se $\times$ C

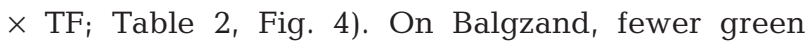
females than green males were present, whereas the abundance of red females was higher than that of red males. On Ballastplaat, more green males than green females were present, but the abundance of red males and females did not differ. On Waardgronden, more green than red crabs were present and this applied to both sexes. The abundances of green and red crabs 


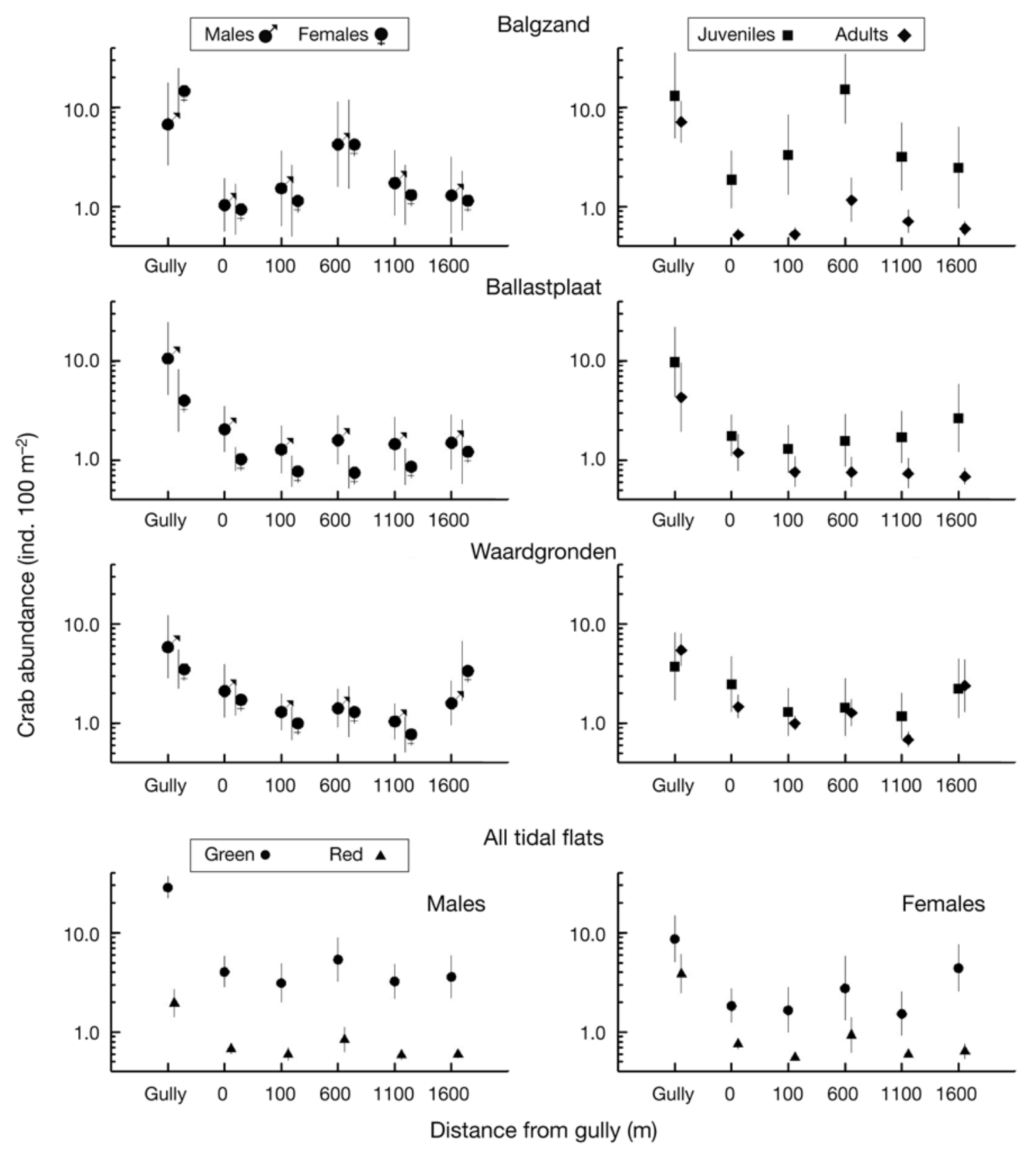

Fig. 3. Carcinus maenas. Abundances in relation to distance from the gully. The top 6 panels show this relationship as observed on each tidal flat for males and females (left), and for juveniles and adults (right). The bottom 2 panels also show this relationship as averaged over all tidal flats for green and red males (left) and females (right). Vertical lines: SE bars

also differed between juveniles and adults. The difference in the abundances of green and red crabs was greater for juveniles than for adults (highly significant interaction $\mathrm{C} \times \mathrm{Si}$ ). The latter interaction, again, also differed between tidal flats (significant interaction $\mathrm{D} \times$ Se $\times T_{F}$; Table 2). The abundance of green crabs was highest on Balgzand, which was mainly due to the high abundance of green juveniles relative to that of red juveniles, whereas there was no difference in the abundances of green and red adults. A similar but weaker pattern was evident on Ballastplaat. On Balgzand and Ballastplaat, the abundances of red juveniles and red adults were similar, but more red adults than red juveniles were present on Waardgronden. On all tidal flats, more green juveniles than green adults were present (Fig. 4).

The abundances of green and red crabs not only varied between males and females (significant interaction 


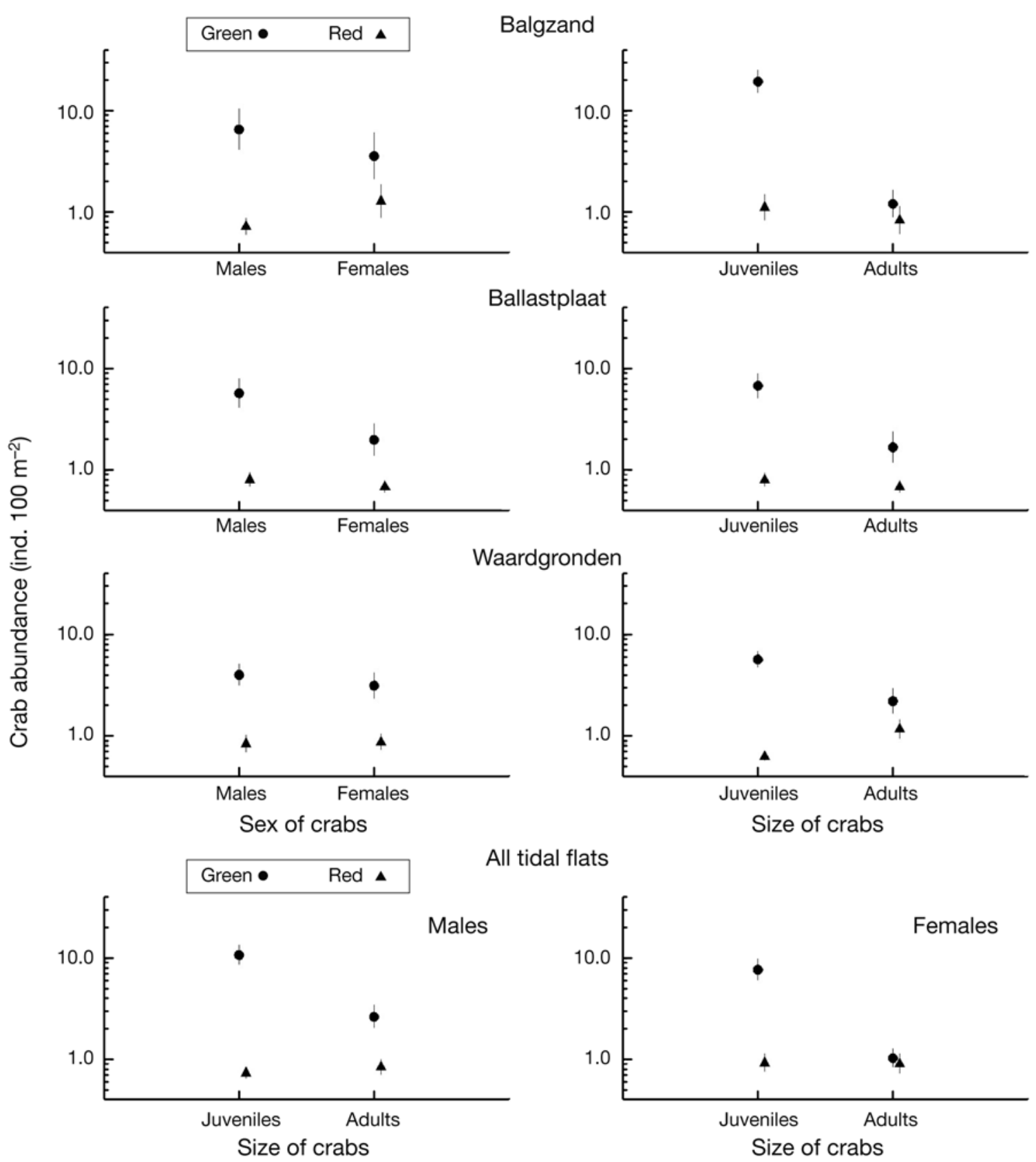

Fig. 4. Carcinus maenas. Abundances in relation to sex and size. The top 6 panels show this relationship as observed on each tidal flat for green and red crabs. The bottom 2 panels show this relationship as averaged over all tidal flats for green and red males (left) and females (right). Vertical lines: SE bars

Se $\times$ C), but also between juveniles and adults (significant interaction $\mathrm{Se} \times \mathrm{C} \times \mathrm{Si}_{\text {; }}$ Table 2, Fig. 4): the abundance of green juveniles was higher than that of red juveniles, both for males and females. However, the abundance of green adult males was higher than that of red adult males, whereas the abundance of green and red adult females did not differ. The interaction $\mathrm{C} \times \mathrm{Si}$ was very significant, which revealed for both 3 -way interactions $\mathrm{D} \times \mathrm{Se} \times \mathrm{TF}$ and $\mathrm{Se} \times \mathrm{C} \times \mathrm{Si}$ that the difference in green and red juveniles was much larger than the difference in green and red adults.

\section{Brown shrimps and infauna: variation in abundances}

On each tidal flat, the abundance of small shrimps increased with distance from the gully, whereas the abundance of large shrimps was highest in the gully 
and decreased with distance from it (significant interaction $\mathrm{D} \times \mathrm{Si}_{\text {; }}$ Table 3, Fig. 5). The significant main effect $\mathrm{Si}$ (Table 3) indicates that on average there were more small shrimps than large ones. The distribution of shrimps was similar across the 3 tidal flats (insignificant effect of TF; Table 3). The density of infauna was higher on Ballastplaat than on Waardgronden and Balgzand (Table 3, Fig. 5). On all tidal flats, the density of infauna increased with increasing distance from the gully (Table 3, Fig. 5).

\section{Ideal free distribution tests}

Ideal free distribution model

We used the 2-phenotypes interference model (Smallegange \& van der Meer 2009) to derive ideal free predictions. Adult crabs were assigned to the class of dominants, and juveniles to the subordinates class.

Briefly, the model essentials are as follows: dominants and subordinates can be in one of the following behavioural states: searching for food, handling food, or interfering with others. Interference consists of threatening, avoiding, fighting and being vigilant (only towards equal competitors). Dominants only interfere with other dominants; subordinates suffer interference from other subordinates and from dominants. Interference occurs while searching or handling, but handlers do not interfere with other handlers. The specific transition rules between the different behavioural states are captured in a set of 5 ordinary differential equations (Supplement 1, avail-

Table 3. Crangon crangon and infauna. ANOVA of (logtransformed) abundance. Values in bold: $\mathrm{p}<0.05$

\begin{tabular}{|lcrcr|}
\hline Factor & df & MS & $F$ & $\mathrm{p}$ \\
\hline Shrimps: between plots & & & & \\
Tidal flat (TF) & 2 & 1.093 & 4.068 & 0.076 \\
Error & 6 & 0.269 & & \\
Shrimps: within plots & & & & \\
Distance (D) & 5 & 1.818 & 1.209 & 0.329 \\
D $\times$ TF & 10 & 1.928 & 1.282 & 0.284 \\
Error & 30 & 1.504 & & \\
Size (Si) & 1 & 4.637 & 8.489 & $\mathbf{0 . 0 2 7}$ \\
Si $\times$ TF & 2 & 0.543 & 0.993 & 0.424 \\
Error & 6 & 0.546 & & \\
D $\times$ Si & 5 & 11.494 & 20.570 & $<\mathbf{0 . 0 0 1}$ \\
D $\times$ Si $\times$ TF & 10 & 0.506 & 0.906 & 0.540 \\
Error & 30 & 0.559 & & \\
Infauna: between plots & & & & \\
Tidal flat (TF) & 2 & 10.930 & 12.177 & $\mathbf{0 . 0 0 8}$ \\
Error & 6 & 0.898 & & \\
Infauna: within plots & & & & \\
Distance (D) & 5 & 8.449 & 6.530 & $<\mathbf{0 . 0 0 1}$ \\
D $\times$ TF & 10 & 1.499 & 1.158 & 0.355 \\
Error & 30 & 1.294 & & \\
\hline
\end{tabular}
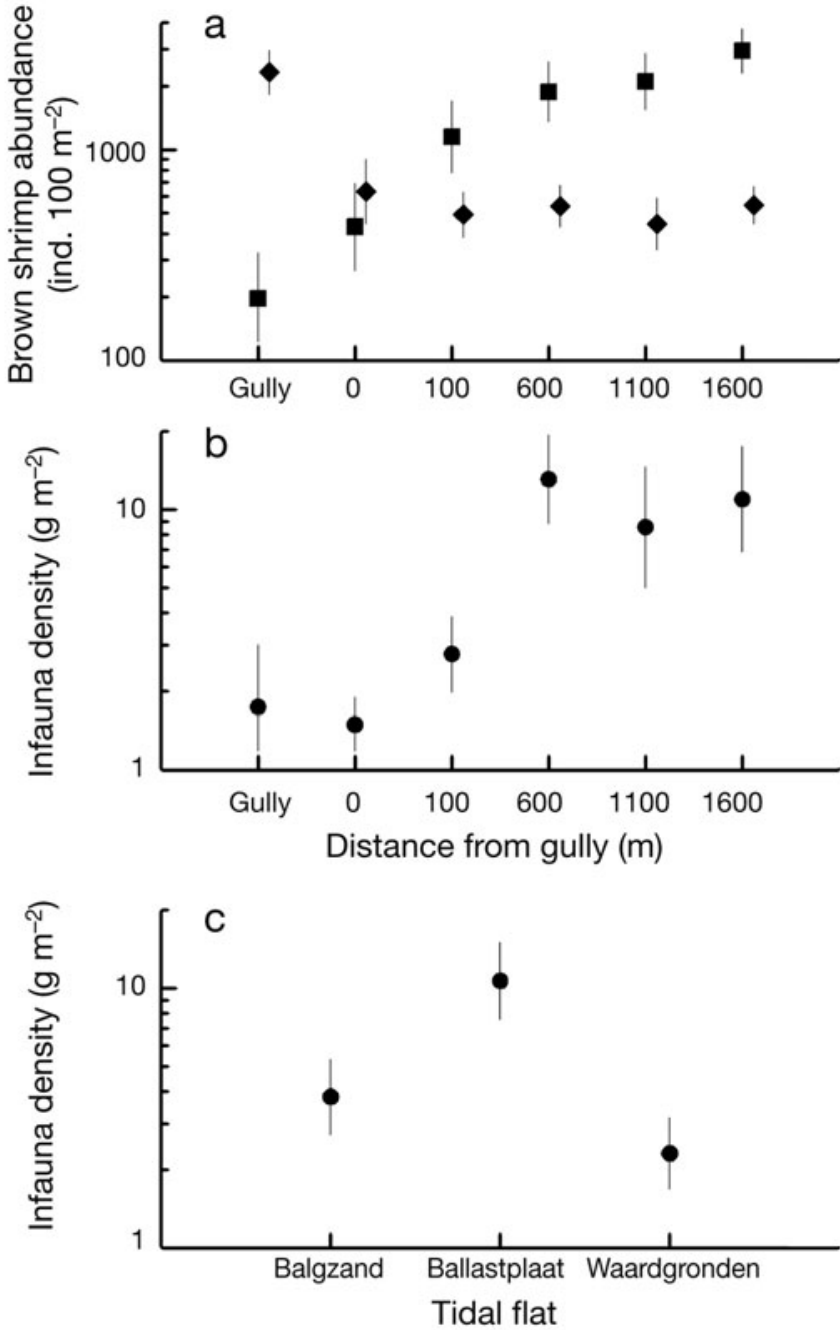

Fig. 5. Crangon crangon and infauna. Changes in prey abundance with distance from the gully or between tidal flats. Shrimp abundances are in no. per $100 \mathrm{~m}^{2}$ and infauna densities are in $\mathrm{g} \mathrm{m}^{-2}$. (a) On all tidal flats, the abundance of small brown shrimps (ם) increased with increasing distance from the gully, whereas the abundance of large brown shrimps ( was high in the gully, but lower on tidal flats. (b) The density of infauna increased with increasing distance from the gully on all tidal flats. (c) On average, the density of infauna was higher on Ballastplaat than on Balgzand and Waardgronden. Vertical lines in all panels: SE bars

able at: www.int-res.com/articles/suppl/m392p143_app. pdf). The expected per capita feeding rate $(W)$ of dominants and subordinates is derived from these equations (Supplement 1) as:

$$
W=v D \frac{b}{2 a}\left(-1+\sqrt{1+\frac{4 a}{b^{2}}}\right)
$$

For both adults and juveniles, $a=P\left[\frac{\xi}{\zeta}+\frac{\mu}{\varphi}\left(1+\frac{2 v D}{\lambda}\right)\right]$ where $P$ is the number of adults or juveniles at the different sampling sites $\left(\right.$ no. $\mathrm{m}^{-2}$ ), $D$ is the prey density at 
the different sampling sites (no. $\mathrm{m}^{-2}$ ), $\lambda$ is the inverse of the time spent handling a prey item, $\varphi$ is the inverse of the time spent interfering, $\xi / \zeta$ is the interference area, $v$ is the searching efficiency, and $\mu$ is the rate of predator discovery. For adults, $b=1+\frac{v D}{\lambda}$, while $b=1+\frac{v D}{\lambda}+\frac{\mu}{\varphi}\left(1+\frac{2 v D}{\lambda}\right)\left(-1+\sqrt{1+\frac{4 a}{b^{2}}}\right) \frac{b P_{\mathrm{A}}}{2 a}$ for juveniles, where $P_{\mathrm{A}}$ is the density of adults.

\section{Parameterisation}

Multivariate analysis revealed that the abundance of crabs of nearly all 8 classes correlated positively with the abundance of large brown shrimps (Fig. 2), which was the first prey category. Parameter values used in the IFD tests with large shrimps as prey were (Smallegange \& van der Meer 2009): $\varphi=1 / 4.4 \mathrm{~s}, \xi / \zeta=0.81 \mathrm{~m}^{2}$, $v=4.0 \times 10^{-4} \mathrm{~m}^{2} \mathrm{~s}^{-1}, \mu=18.9 \times 10^{-3} \mathrm{~m}^{2} \mathrm{~s}^{-1}$. These parameter values were estimated from observations of shore crabs foraging on blue mussels, and the foraging parameters $v$ and $\lambda$ (searching efficiency and inverse of handling time) might not be representative for shore crabs foraging on shrimps. Therefore, in our ideal free distribution tests, we additionally explored the effects of a 10-fold decrease and a 10-fold increase in the default value of the searching efficiency $v$. We were unable to find estimates of the time that shore crabs need to handle a brown shrimp $\left(\lambda^{-1}\right)$. In blue crabs Callinectes sapidus, the average handling time of a white shrimp Litopenaeus setiferus of medium to large size (40 to $90 \mathrm{~mm}$ total length) was on average $600 \mathrm{~s}$ (Mascaró et al. 2003). The size ratio of large brown shrimps relative to adult shore crabs is similar to that of white shrimps relative to blue crabs; therefore, we assumed that the time required by a shore crab to handle a brown shrimp is also $600 \mathrm{~s}$. We assumed that a juvenile needs 200 s more to handle a large brown shrimp.

The second prey category for the IFD tests was infauna, which mainly consisted of bivalve prey species. Since the 2-phenotypes interference model was originally parameterised for shore crabs foraging on mussels, we used the default parameter values (Smallegange \& van der Meer 2009): $\varphi=1 / 4.4 \mathrm{~s}, \xi / \zeta=0.81 \mathrm{~m}^{2}$, $v=4.0 \times 10^{-4} \mathrm{~m}^{2} \mathrm{~s}^{-1}, \mu=18.9 \times 10^{-3} \mathrm{~m}^{2} \mathrm{~s}^{-1}, \lambda^{-1}=108.5$.

Testing ideal free predictions

The first IFD test compared the observed and the predicted distributions of shore crabs. To avoid cycling of individuals between patches, IFDs are best derived for a system consisting of 2 food patches: a rich and a poor patch. The IFD is then one where no individual can achieve a higher feeding rate by moving from one patch to the other. This requires that the distribution of predator type $i$ will be at equilibrium when the per capita feeding rate in the rich $(r)$ patch equals that in the poor $(p)$ patch:

$$
W(i, r)=W(i, p)
$$

or when all individuals of each predator type are on the rich patch. With respect to the first prey category, we observed that the abundance of large shrimps was high in the gullies and low across the tidal flats (Fig. 5). Since abundance values did not differ between sampling sites on the 3 tidal flats (Fig. 5; SEs overlap), we assigned the average of those values (531 per $100 \mathrm{~m}^{2}$ ) to the poor food patch and the average abundance of large shrimps in the gullies was taken as the value for the rich patch (2329 per $100 \mathrm{~m}^{2}$ ). Similar to Smallegange \& van der Meer (2009), ideal free predictions using Eq. (2) (Supplement 2; www. int-res.com/articles/suppl/m392p143_app.pdf) were derived for the full range of crab densities observed (1 to 64 crabs per $100 \mathrm{~m}^{2}$; numbers divided equally between dominants and subordinates). It turned out that the IFD was always one where all crabs were on the rich patch, regardless of crab density, and regardless of a 10-fold increase or decrease in searching efficiency. We performed the same analysis for the second prey category, infauna. Again, prey abundances could be lumped into 2 categories as abundance values were similar across sampling sites in the gully and at 0 to $100 \mathrm{~m}$ from it, and between sampling sites at 600 to $1600 \mathrm{~m}$ from the gully (Fig. 5). The average of the first set of values was assigned to the poor patch, while the average of the second set was assigned to the rich patch. We performed this IFD test separately for each tidal flat as infauna densities differed between tidal flats (Table 3 ). The values for the poor patch were 3.8, 2.2 and $5.6 \mathrm{~g}$ per $100 \mathrm{~m}^{2}$, and 50.6, 13.0 and $6.0 \mathrm{~g}$ per $100 \mathrm{~m}^{2}$ for the rich patch for Ballastplaat, Balgzand, and Waardgronden, respectively. Again, it turned out that the IFD was always one where all crabs were on the rich patch regardless of crab density, except for Waardgronden where a mixed distribution, with both adults and juveniles in both patches, was predicted for crab densities $>16$ per $100 \mathrm{~m}^{2}$.

The second test assessed whether the expected per capita feeding rates of crabs were in line with ideal free predictions. An assumption of the 2-phenotypes interference model is that dominant predators only suffer interference from equal (i.e. other dominant) competitors. The ideal free distribution for equal competitors is one where the per capita feeding rate of individuals is equal across different feeding sites (Fretwell \& Lucas 1969). We tested this hypothesis by calculating the expected per capita feeding rate of adult crabs (dominants) in relation to prey density and competitor density on each sampling site using Eq. (1). 
In Eq. (1), $P$ is now the number of adults and $D$ is the prey density at the different sampling sites. Expected feeding rates were log-transformed before analysis. With shrimps as prey, the resulting expected per capita feeding rates did not differ between tidal flats $\left(F_{2,6}=\right.$ $3.1, p=0.12)$. The effect of distance from the gully was marginally insignificant $\left(F_{5,30}=2.5, \mathrm{p}=0.06\right)$ (Fig. 6). The interaction between tidal flat and distance from the gully was also insignificant $\left(F_{10,30}=1.2, \mathrm{p}=0.31\right)$. A 10 -fold decrease in searching efficiency resulted in significant effects of tidal flat $\left(F_{2,6}=6.2 \mathrm{p}=0.04\right.$; Balgzand $<$ Ballastplaat $=$ Waardgronden) and distance from the gully $\left(F_{5,30}=9.4, \mathrm{p}<0.01\right)$ on expected per capita feeding rates (Fig. 6), but the interaction remained insignificant $\left(F_{10,30}=1.9, \mathrm{p}=0.09\right)$. A 10 -fold increase in searching efficiency resulted in insignificant effects of tidal flat $\left(F_{2,6}=2.7 \mathrm{p}=0.15\right)$, distance from the gully $\left(F_{5,30}=2.0, \mathrm{p}=0.12\right)$ and interaction between the 2 factors $\left(F_{10,30}=1.2, \mathrm{p}=0.31\right)$ on expected per capita feeding rates. With infauna as prey, the resulting expected per capita feeding rates did not differ between tidal flats $\left(F_{2,6}=4.4, \mathrm{p}=0.07\right)$. Expected feeding rates increased with increasing distance from the gully $\left(F_{5,30}=5.6, \mathrm{p}<0.01\right)$ (Fig. 6). The interaction between tidal flat and distance from the gully was insignificant $\left(F_{10,30}=0.9, \mathrm{p}=0.51\right)$.

\section{DISCUSSION}

In this study, we investigated the spatial distribution of shore crabs in relation to their morphology, prey availability and the number of conspecifics in different feeding areas. The number of males and females varied between sampling sites and between mudflats, but overall, more were found in the gully adjacent to each mudflat than on the mudflat. There was one exception to this pattern: at $600 \mathrm{~m}$ from the gully on Balgzand, there was a peak in crab abundance. This peak was predominantly due to a peak in the number of juveniles, which occurred abundantly on Balgzand. In contrast to the situation on Ballastplaat and on Waardgronden, the overall abundance of juveniles was much higher than that of adults on Balgzand. Balgzand is a well-known nursery ground for many species (Zijlstra 1972, van Beek et al. 1989, van der Veer et al. 2001) and this might explain the high abundance of juveniles on the Balgzand mudflat.

Depending on their moult stage, shore crabs differ in colour and in their tolerance to extreme environmental conditions (McGaw \& Naylor 1992, Reid et al. 1997). In our field study, the abundance of green crabs was higher than that of red crabs, and this difference was more pronounced in juveniles than in adults, and, except for Waardgronden, more pronounced in males

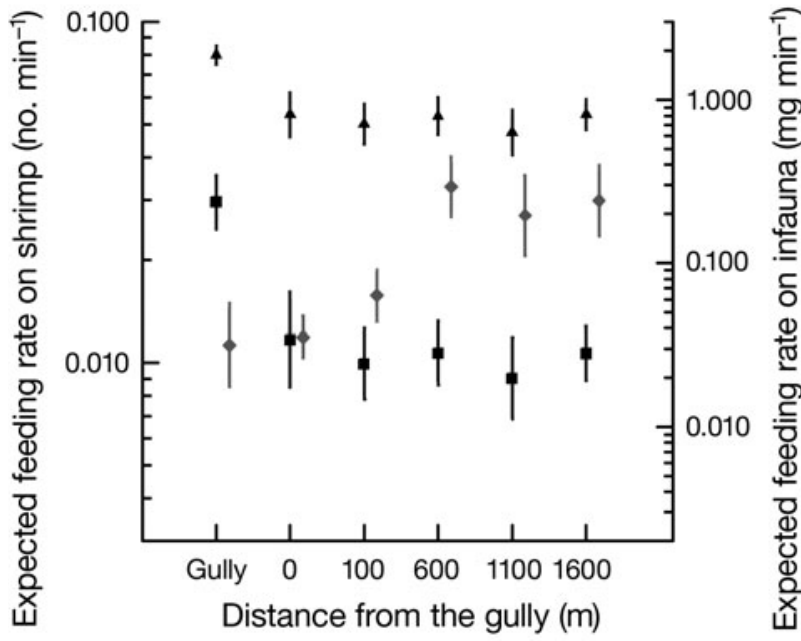

Fig. 6. Carcinus maenas. Expected feeding rates of adult on shrimps (no. $\mathrm{min}^{-1}$; black symbols) $( \pm \mathrm{SE})$ and on infauna (mg $\mathrm{min}^{-1}$; grey symbols) $( \pm \mathrm{SE})$ as a function of distance from the gully. Shrimp feeding rates were calculated using default values $(\mathbf{\Lambda})$ and with the searching efficiency $v$ decreased by 10 -fold (-)

than in females. Possibly related to their higher physiological tolerance, green crabs show more tidal migration than red crabs (Hunter \& Naylor 1993), although we did not observe such a pattern (Table 3: the interactions ' $\mathrm{D} \times \mathrm{C}^{\prime}$ and ' $\mathrm{D} \times \mathrm{C} \times \mathrm{TF}^{\prime}$ ' were insignificant). Instead, a more complex distribution pattern was observed in which the migratory behaviour of shore crabs of different colours also depended on their sex. Most males were found in the gully adjacent to each mudflat and abundances on the mudflat were generally low. This pattern was the same for green and red males, which refutes the hypothesis that green males show tidal migration to escape competition from the more dominant red males (Styrishave et al. 2004). Red females showed a similar distribution as males, with relatively high abundance values in the gullies, but low values on the mudflats. We carried out our field study during the mating season. In order to mate, females have to moult (Berrill \& Arsenault 1982), which might explain why red females congregated in areas where the number of males was high (or possibly vice versa) (van der Meeren 1994). In contrast to the males, however, the abundance of green females in the gullies was similar to that of red females, and was also high at farther distances from the gullies. Males are known to be more migratory than females (Hunter \& Naylor 1993), but our results suggest that the migratory behaviour of shore crabs depends in an interactive way on the colour and sex of individuals.

This field study revealed that the observed abundances of shore crabs in the gully adjacent to each mudflat and on the mudflats varied with variation in 
the sex and size of crabs. Using IFD theory, we further explored this pattern to establish if crabs distributed themselves in an optimal way in relation to 2 prey types (brown shrimps and infauna, mainly bivalves) at the different sampling sites and to the number of competitors present. The prey types were distributed in similar ways on each mudflat. It turned out that if crabs predominantly foraged on either of those prey types, they did not distribute themselves optimally as all crabs were predicted to forage in the areas that contained the highest prey abundance. In the case of brown shrimps, the most profitable areas were the gullies, while in the case of infauna, these areas were 600 to $1600 \mathrm{~m}$ away from the gullies. Furthermore, the expected feeding rates of adults were higher in these most profitable areas than in other areas, implying that crabs that were not in the most profitable areas could have increased their (expected) feeding rate by moving to the high prey abundance areas. IFD theory adopts a simplified view of reality, and our IFD model does not take differences in crab colour, morphology or sex into account. This might explain why crabs appeared not to behave in an optimal manner, although we could not expect crabs to always behave optimally since they are bound to sample unprofitable parts of the mudflats (Hugie \& Grand 1997).

The mismatch between the predicted optimal distribution and the observed distribution of shore crabs could also be explained by other factors. For example, a crucial assumption of IFD theory is that travelling costs between feeding areas are negligible (Fretwell \& Lucas 1969). This assumption is likely to have been met for crabs that forage and reside exclusively in the gullies or on the mudflats. Yet, shore crabs that migrate may lose foraging time. They may also lose energy associated with moving, although these costs may be low if crabs are able to use water currents when migrating onto and off the tidal flats. Furthermore, shore crabs prefer to forage at night (Afman 1980, Ansell et al. 1999), most likely to avoid predation by birds or other predators that rely on vision for hunting (Dumas \& Witman 1993). If high tide occurs at night, the food intake of shore crabs foraging on the mudflats is indeed at its highest (Afman 1980). However, it is not known whether shore crabs reside in the gullies merely to reduce the risk of predation during the day, or whether they also forage for prey, such as brown shrimps, in the gullies (Afman 1980). It might even be that the brown shrimps themselves reduce that same predation risk by residing in the gullies during the day, and that both crustacean species might migrate onto the mudflats to forage at night. Another factor affecting the distribution of shore crabs (at least those crabs that are $<12 \mathrm{~mm} \mathrm{CW}$ ) is cannibalism (Moksnes 2004). To what extent avoiding the risk of predation by adults might have motivated the juveniles (10 to $35 \mathrm{~mm} \mathrm{CW}$ ) in our samples to move from the gullies onto the tidal flats, or to stay on the tidal flats during low tide, is not known. However, reducing the risk of predation by conspecifics is a likely explanation for the general observation of different habitats for juvenile and adult shore crabs (Hunter \& Naylor 1993).

Despite the shortcomings of the IFD exercise, there are still several lessons to be learned from it. Firstly, 2 distinct foraging areas seemed to exist for shore crabs: gullies with shrimps as prey and mudflats with bivalves as prey. An IFD model incorporating food patches characterised by different prey types would therefore be more suitable for future efforts testing predictions on the optimal foraging behaviour of shore crabs. Secondly, half of the total number of crabs caught was collected in the gullies where the abundance of large brown shrimps was also highest. This pattern was captured by the RDA analysis, where we found a positive correlation between the abundance of crabs and that of large shrimps. A species related to the shore crab, the blue crab Callinectes sapidus, prefers larger shrimps to smaller ones and even consumes shrimps of a larger body size than its own (Mascaró et al. 2003). We are not aware of studies that have investigated to what extent shore crabs prefer brown shrimps over other prey species, or what shrimp size shore crabs prefer, but brown shrimps make up a large part (up to $50 \%$ ) of the shore crab's diet (Afman 1980, Pihl 1985). This suggests that shore crabs might reside in the gullies to forage on this profitable prey species. Current studies on predation by shore crabs have mostly focussed on the predation pressure they exert on bivalve species (Eggleston et al. 1992, Mascaró \& Seed 2000, 2001, Mistri 2003). The role that shore crabs might play in the population dynamics of shrimps and vice versa remains to be explored.

In summary, a superficial look at the results showed a high congregation of crabs in the gullies, where the abundance of brown shrimps (a dominant prey species of shore crabs) was also high. A more detailed investigation revealed that the spatial distribution of crabs between the gullies and the mudflats depended in an interactive way on the colour morph and sex of individuals. These factors were not included in the IFD model, and neither were food patches in the IFD model characterised by different prey types, which could possibly explain the mismatch between the observed and the predicted distributions. Future research focussed on testing the optimal foraging behaviour of shore crabs should therefore include these factors, as well as test the foraging preference of shore crabs on shrimps versus bivalve prey species. Field experiments on patch choice using exclosures could elucidate the role of predation in the foraging decisions of shore crabs. 
Acknowledgements. We thank R. Dekker, C. Kraan, T. Piersma, and T. van der Vis for help in identifying suitable tidal flats for the fieldwork; M. Brugge, D. Waasdorp, and H. Witte for assistance with crab and prey sampling; and $\mathrm{H}$. Witte for help in sorting out shrimp samples. Transport was provided by E. Adriaans on board the RV 'Stern'. We also thank M. Sabelis for comments on the manuscript and constructive advice on the analyses, W. Vahl for discussion of the results, and $M$. Antheunisse for drawing the map shown in Fig. 1. I.M.S. was financially supported by a research grant from the Netherlands Organization for Scientific Research awarded to J.v.d.M. The study conformed to Dutch law on the use of animals in ecological studies.

\section{LITERATURE CITED}

Aagaard A, Warman CG, Depledge MH, Naylor E (1995) Dissociation of heartbeat rate and locomotor activity during the expression of rhythmic behaviour in the shore crab Carcinus maenas. Mar Freshw Behav Physiol 26:1-10

Afman BP (1980) De voedselopname van de strandkrab Carcinus maenas (L.). NIOZ-rapport 1980-4

Alonso JC, Bautista LM, Alonso JA (1997) Dominance and the dynamics of phenotype-limited distribution in common cranes. Behav Ecol Sociobiol 40:401-408

Ansell AD, Comely CA, Robb L (1999) Distribution, movements and diet of macrocrustaceans on a Scottish sandy beach with particular reference to predation on juvenile fishes. Mar Ecol Prog Ser 176:115-130

Bautista LM, Alonso JC, Alonso JA (1995) A field test of ideal free distribution in flock-feeding common cranes. J Anim Ecol 64:747-757

Berrill M, Arsenault M (1982) Mating behavior of the green shore crab Carcinus maenas. Bull Mar Sci 32:632-638

Cohen AN, Carlton JT, Fountain MC (1995) Introduction, dispersal and potential impacts of the green crab Carcinus maenas in San Francisco Bay, California. Mar Biol 122: 225-237

Crothers JH (1968) The biology of the shore crab Carcinus maenas (L.) 2. The life of the adult crab. Field Stud 2: 579-614

Dare PJ, Edwards DB (1981) Underwater television observations on the intertidal movement of shore crabs, Carcinus maenas, across a mudflat. J Mar Biol Assoc UK 61:107-116

Dumas JV, Witman JD (1993) Predation by herring gulls (Larus argentatus Coues) on two rocky intertidal crab species (Carcinus maenas [L.] and Cancer irroratus Say). J Exp Mar Biol Ecol 169:89-101

Eggleston DB, Lipcius RN, Hines AH (1992) Density-dependent predation by blue crabs upon infaunal clam species with contrasting distribution and abundance patterns. Mar Ecol Prog Ser 85:55-68

Fretwell SD, Lucas HL (1969) On territorial behavior and other factors influencing habitat distribution in birds. Acta Biotheor 19:16-36

> Hugie DM, Grand TC (1997) Movement between patches, unequal competitors and the ideal free distribution. Evol Ecol 12:1-19

Hunter E, Naylor E (1993) Intertidal migration by the shore crab Carcinus maenas. Mar Ecol Prog Ser 101:131-138

> Kaiser MJ, Hughes RN, Reid DG (1990) Chelal morphometry, prey-size selection and aggressive competition in green and red forms of Carcinus maenas (L.). J Exp Mar Biol Ecol 140:121-134

> Lee KT, Jivoff P, Bishop RE (2005) A low cost, reliable method for quantifying coloration in Carcinus maenas (Linnaeus,
1758) (Decapoda, Brachyura). Crustaceana 78:579-590

Manly BFJ (1997) Randomization, bootstrap and Monte Carlo methods in biology. Chapmann \& Hall/CRC, Boca Raton, FL

Mascaró M, Seed R (2000) Foraging behavior of Carcinus maenas (L.): comparisons of size-selective predation on four species of bivalve prey. J Shellfish Res 19:283-291

- Mascaró M, Seed R (2001) Foraging behaviour of juvenile Carcinus maenas (L.) and Cancer pagurus L. Mar Biol 139: 1135-1145

> Mascaró M, Hidalgo LE, Chiappa-Carrara X, Simoes N (2003) Size-selective foraging behaviour of blue crabs, Callinectes sapidus (Rathbun), when feeding on mobile prey: active and passive components of predation. Mar Freshw Behav Physiol 36:143-159

> McGaw IJ, Naylor E (1992) Salinity preference of the shore crab Carcinus maenas in relation to coloration during intermoult and to prior acclimation. J Exp Mar Biol Ecol 155: 145-159

> Milinski M, Bolgshauser P, Büchi L, Buchwalder T and others (1995) Competition for food in swans: an experimental test of the truncated phenotype distribution. J Anim Ecol 64: $758-766$

Mistri M (2003) Foraging behaviour and mutual interference in the Mediterranean shore crab, Carcinus aestuarii, preying upon the immigrant mussel Musculista senhousia. Estuar Coast Shelf Sci 56:155-159

Mitchell SC, Kennedy SM, Williams PJ, DeMont ME (2003) Morphometrics and estimates of force generation by the chelae of a North American population of the invasive green crab, Carcinus maenas (L.). Can J Zool 81: 203-215

Moksnes PO (2004) Interference competition for space in nursery habitats: density-dependent effects on growth and dispersal in juvenile shore crabs Carcinus maenas. Mar Ecol Prog Ser 281:181-191

Pihl L (1985) Food selection and consumption of mobile epibenthic fauna in shallow marine areas. Mar Ecol Prog Ser 22:169-179

Reid DG, Abelló P, Kaiser MJ, Warman CG (1997) Carapace colour, inter-moult duration and the behavioural and physiological ecology of the shore crab Carcinus maenas. Estuar Coast Shelf Sci 44:203-211

Reise K (1985) Tidal flat ecology. An experimental approach to species interactions. Springer-Verlag, Berlin

Sanchez-Salazar ME, Griffiths CL, Seed R (1987) The effect of size and temperature on the predation of cockles Cerastoderma edule (L.) by the shore crab Carcinus maenas (L.). J Exp Mar Biol Ecol 111:181-193

Smallegange IM, Van der Meer J (2007) Interference from a game theoretical perspective: shore crabs suffer most from equal competitors. Behav Ecol 18:215-221

Smallegange IM, Van der Meer J (2009) The distribution of unequal predators across food patches is not necessarily (semi)-truncated. Behav Ecol 20:525-534

- Smallegange IM, Van der Meer J, Kurvers RHJM (2006) Disentangling interference competition from exploitative competition in a crab-bivalve system using a novel experimental approach. Oikos 113:157-167

Styrishave B, Rewitz K, Andersen O (2004) Frequency of moulting by shore crabs Carcinus maenas (L.) changes their colour and their success in mating and physiological performance. J Exp Mar Biol Ecol 313:317-336

ter Braak CJF, Šmilauer P (1998) CANOCO reference manual and user's guide to CANOCO for Windows: software for Canonical Community Ordination (v. 4). Microcomputer Power, Ithaca, NY 
van Beek FA, Rijnsdorp AD, De Clerck R (1989) Monitoring juvenile stocks of flatfish in the Wadden Sea and the coastal areas of the southeastern North Sea. Helgol Meersunters 43:461-477

van der Meeren GI (1994) Sex- and size-dependent mating tactics in a natural population of shore crabs Carcinus maenas. J Anim Ecol 63:307-314

van der Veer HW, Feller RJ, Weber A, Witte JIJ (1998) Importance of predation by crustaceans upon bivalve spat in the intertidal zone of the Dutch Wadden Sea as revealed by immunological assays of gut contents. J Exp Mar Biol Ecol 231:139-157

van der Veer HW, Dapper R, Witte JIJ (2001) The nursery function of the intertidal areas in the western Wadden sea

Editorial responsibility: Roger Hughes,

Bangor, UK for 0-group sole Solea solea (L.). J Sea Res 45:271-279

Vernberg FJ, Vernberg WB (eds) (1983) The biology of crustacea. Environmental adaptations, Vol 8. Academic Press, New York

Warman CG, Reid DG, Naylor E (1993) Variation in the tidal migratory behaviour and rhythmic light-responsiveness in the shore crab, Carcinus maenas. J Mar Biol Assoc UK 73: 355-364

Whittaker RH, Levin SA (1977) The role of mosaic phenomena in natural communities. Theor Popul Biol 12:117-139

Zijlstra JJ (1972) On the importance of the Wadden Sea as a nursery area in relation to the conservation of the southern North Sea fishery resources. Symp Zool Soc London 29: $233-258$

Submitted: April 6, 2009; Accepted: August 7, 2009

Proofs received from author(s): October 14, 2009 